\title{
Forskningstraditioner krydser deres spor Kvalitative og kvantitative socio-kulturelle empiriske forskningsmetoder
}

\section{Af Inge Henningsen og Dorte Marie SøndergaArd}

Forskelligheder mellem metoderedskaber må forst og fremmest ses $i$ lyset af forskelle mellem de kundskabsambitioner, som redskaberne anvendes $i$ forbold til, og dermed mellem de forskelligartede metateoretiske pramisser, som kundskabsambitionerne er del af. Det illustreves gennem sammenligning mellem kvalitative og kvantitative tilgange til empiriske data.

med artiklen er at problematisere forestillinger om kvalitativ og kvantitativ metode som helt artsforskellige redskaber og derigennem at åbne for en mulig nytænkning af relationen mellem dem. Vi ønsker at vise, hvordan de to metoder inden for visse former for forskningspraksis, trods en række forskelligheder hvad angår fokus og forskningssprog har mange fælles træk.

Artiklen udspringer af vores samarbejde i Konsbarriereprojektet, 1 hvor vi gentagne gange under vores metodediskussioner er blevet slået af lighederne mellem på den ene side DMS' narrative og dekonstruerende tilgange og på den anden side de fremgangsmåder, IH som statistiker bringer i anvendelse, når hun analyserer empiriske datamaterialer. Det er derfor heller ikke en hvilken som helst kvalitativ og kvantitativ forskningspraksis, vi her i artiklen tager udgangspunkt i, når vi diskuterer forskelle og ligheder. 
Den kvalitative empiriske forskning afgrænses i denne sammenhæng til den sociokulturelt analytiske fremgangsmåde, som (f.eks. i en Søndergaard'sk version) sammentænker kulturpsykologiske, konstruktionistiske og poststrukturalistiske former for tænkning i en forskningspraksis, der fokuserer på socio-kulturelle og diskursive formationsbetingelser og subjektiveringsprocesser (se f.eks. Søndergaard, 1996, 1999/2000). De kulturpsykologiske inspirationer hentes hos for eksempel Haavind (1987, 1994), Gulbrandsen (1998), Bruner (1990), Cole (1996). De konstruktionistiske og poststrukturalistiske inspirationer hentes hos for eksempel Butler (1993, 1995, 1997), Foucault (1978), Davies and Harré (1990), Davies (2000), Lather (1993) og Scheurich (1997).

Den kvantitative empirisk forskning, som vi beskæftiger os med her, afgrænses af kundskabsambitioner, der på samme måde som ovenstående har socio-kulturelt medierede individer og deres samfundsmæssige og kulturelle positioner som fokus, men som anvender matematiske og statistiske redskaber til at udforske sådanne positioner (Benzécri et. al., 1973. Bourdieu, 1984, Almegård, 1997. Henningsen, 1998).

Fxlles for de to tilgange ligger en forståelse af det socio-kulturelles og subjektives konstruerede og dermed foranderlige karakter. Redskaberne, som de to traditioner bidrager med, er forfinede til at afdække forskellige aspekter og taler ligeledes i delvist forskellige sprog. For eksempel vil den kvantitative forskning vanskeligt kunne nå særligt langt ind i de subjektiveringsprocesser, som særlige socio-kulturelle betingelser danner præmisserne for, hertil må de kvalitative redskaber bringes i brug. Den kvantitative forskning kan ikke udforske diskursiv konstituering af dikotomier; den når vanskeligt diskursernes magtproducerende konstruktioner, ej heller de subjektive formationsprocesser. Den kan konstatere resultaterne af sådanne processer, vel vidende at det er dem, der ligger i de bevægelser, som statistisk kan undersøges i tid og rum. Denne konstatering af konstitueringens processuelle, materialiserede resultater, kan til gengæld gennemføres langt mere omfattende, end den kvalitative metode som oftest vil have mulighed for at gøre det. Trods disse forskelligheder er der imidlertid en række overraskende ligheder i forskningsprocessen.

Vores oplevelse af modsætning mellem kvalitativ og kvantitativ forskningspraksis er utvivlsomt farvet af det faktum, at vi som henholdsvis psykolog og statistiker kommer fra områder, der uanset deres forskelligheder, internationalt er præget af en stærk og hegemonisk eksperimentel tradition, som specielt presser den kvantitative empiriske forskning til at distancere sig fra kvalitativ metode for at kunne fremstå "videnskabelig". Traditionelt har forskellen mellem kvantitativ empirisk og eksperimentel forskning her været underspillet. Den kvantitative empiriske forskning har $i$ vid udstrækning gjort brug af muligheden for at fremstå som "eksperimentelt videnskabelig" for derigennem at få del i den eksperimentelle videnskabs hævdvundne prestige.

Vort forslag er, at den nuværende demarkationslinie mellem kvalitativ og kvantitativ forskning flyttes, således at hovedskellet kommer til at gå mellem eksperimentel og empirisk forskning. Ved at ophæve det skarpe skel mellem kvalitativ og kvantitativ forskning opstår der helt umiddelbart den fordel for den kvantitative forskningstradition, at den får adgang til den kvalitative forskningstraditions mere udviklede praksis omkring eksplicit medrefleksion af forskningsprocessen. Her tilbydes den kvantitative empiriske forskning redskaber til en italesættelse af en forskningspraksis, der allerede eksisterer inden for visse forskningsretninger. For selv om beskrivelsen af den socio-kulturelt analytiske tilgang og for eksempel dens narrativt søgende fremgangsmåder i analysefasen nemlig allerede dækker praksis hos mange, der beskæftiger sig med kvantitative empiriske undersøgelser, så for- 
muleres og erkendes dette generelt ikke eksplicit - noget der formentlig hænger sammen med blokeringer, som har deres udspring i matematikkens klassiske skel mellem analyse og syntese. ${ }^{2}$

Den demarkationslinie, der grundlæggende foreslås flyttet til feltet mellem på den ene side kvantitativ og kvalitativ empirisk forskning og på den anden side eksperimentel forskning, er dog ikke den eneste meningsfulde linie at skabe overblik ved hjælp af. Der vil, som det allerede er fremgået, forekomme endnu et lag af væsentlige afgxnsninger indenfor denne nykonstruerede kategori af empirisk forskning (bestående af såvel kvantitative som kvalitative tilgange), nemlig i forhold til forskningsambitionernes teoretiske antagelser om menneskets relation til sociale og kulturelle kontekster. Formuleret lidt anderledes: forskellighederne formes ikke primært af selve metoden, selve redskabet, men skal først og fremmest ses i lyset af forskelle mellem de kundskabsambitioner, som redskaberne bringes til at forfølge, og dermed mellem de forskelligartede metateoretiske præmisser, som kundskabsambitionerne er del af.

Vi skal lidt senere i artiklen koncentrere os om udviklingen af forskningsspørgsmål og om analytiske fremgangsmåder, når vi mere konkret sammenligner de nævnte arter af kvalitativ og kvantitativ socio-kulturel analyse. Allerførst skal vi imidlertid tillade os at uddybe vores (fagspecifikt situerede) tanker om den hierarkiske relation mellem kvantitativ og kvalitativ empirisk forskning på en måde, der nok fremstår lidt firkantet og provokerende, men måske netop derfor også kan inspirere til diskussion og videretænkning.

POSITIONERINGSPRAKSISSER I KVANTITATIV OG KVALITATIV EMPIRISK FORSKNING

Dagens videnskabssamfund anerkender som nævnt, at kvalitative og kvantitative metoder begge udgør nødvendige repertoi-

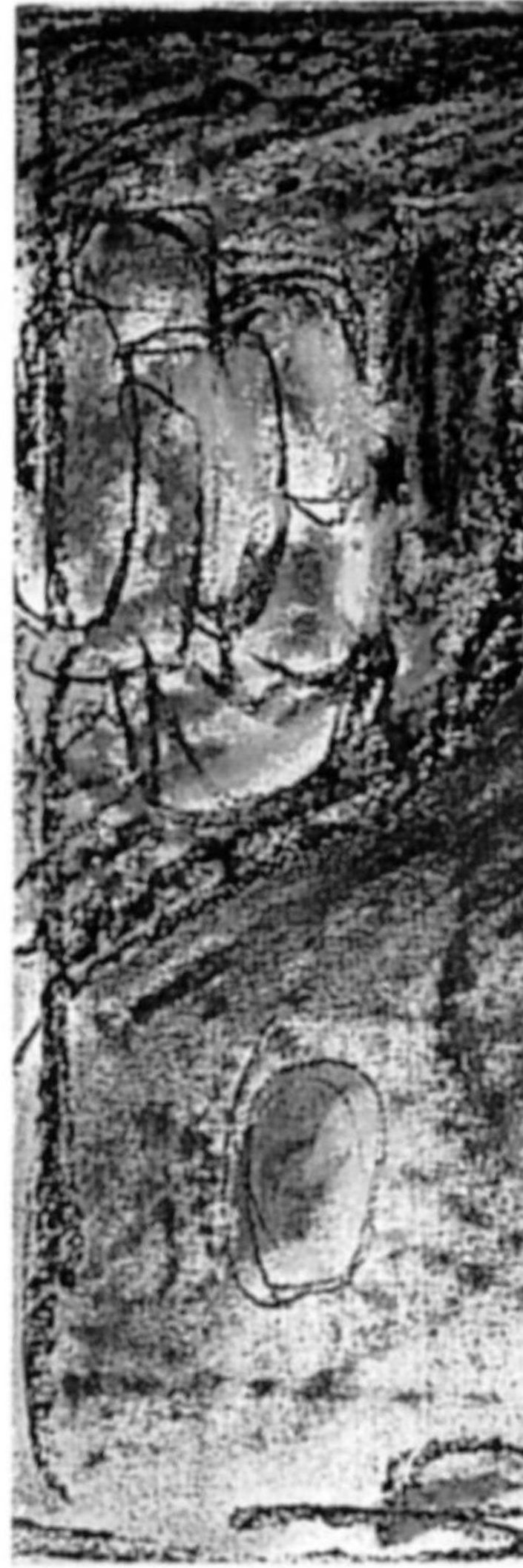


rer af redskaber. Indbygget $i$ anerkendelsen består imidlertid i en række fag en klar hierarkisk relation de to repertoirer imellem. Dette hierarki hænger sammen med den måde, hvorpå prestigesystemerne i det videnskabelige samfund er bygget op: med den naturvidenskabelige forskningspraksis som en form for kerne, og de såkaldt bløde videnskaber, de samfundsvidenskabelige områder og ikke mindst humaniora, som den omgivende periferi. ${ }^{3}$

I dette hierarki er eksperimentet placeret som det mest prestigefyldte, ${ }^{4}$ og indenfor en del fagdiscipliner opnår den kvantitative empiriske forskning prestige i forhold til, hvor eksperimentel den kan fremstå. Indenfor denne konstruktion vil den kvantitative empiriske forskning således ved at positionere sig som en modpol til den kvalitative empiriske forskning opnå at blive den førstehed, den kvalitative empiriske forskning bliver andetgjort i forhold til. Der følger forskellige hierarkiske fordele med denne førsteposition, som nok kan få positionens aktører til at tænke sig om to gange, før de giver sig i kast med at demaskere forskningspraksisens objektive forklædning.

Førstehedspositionen har imidlertid også omkostninger. Holder vi os til den kvantitative empiriske forsknings position, betales de hierarkiske fordele med en fastlåsthed i påstandene om kategorier og undersøgelsesresultater som dækkende og sande. Fastlåstheden hæmmer refleksionsprocessen, når det drejer sig om egen praksis: både den reflekterende proces, der drejer sig om at udforske og italesætte denne praksis og den proces, som drejer sig om at udvikle de analytiske muligheder og undersøge potentielle kundskabsgenererende analysetilgange, der kunne ligge i grænseområderne for eller udenfor den konventionelle praksis. Risikoen for at falde ud af den polært konstituerede position og for at blive mistænkt for at benytte ad-hoc fremgangsmåder kan resultere $i$, at man som kvantitativ empirisk forsker holder sig snævert til (eller foregiver at holde sig snævert til) det konventionelle.
Hvis man betragter den grundlæggende videnskabelige konstituent som en dualisme mellem hverdagsforståelse, på den ene side, og videnskabelig tænkning og praksis på den anden side, så er altså polariseringen mellem kvantitativ og kvalitativ forskning endnu en dualisme, der er konstitueret indenfor visse dele af den videnskabelige tænknings polgrænser til yderligere at differentiere videnskabelighed $\mathrm{i}$ forhold til en kerne og en periferi. Kvalitativ og kvantitativ empirisk forskning falder her begge indenfor grænsen af det videnskabelige, men ser vi på trusselsmønstrene for henholdsvis kvantitativ og kvalitativ empirisk forskning, i fald de overtræeder de etablerede normer for relevant forskningspraksis, så ligger truslen for den kvantitative forskning $i$ at glide ud i den kvalitative forsknings relativt marginaliserede position, mens truslen for den kvalitative empiriske forskning ligger $i$ at blive skubbet ud af kategorien 'videnskabelig' og over i kategorien "uvidenskabelig", "hverdagstænkning”, eventuelt og som et nok så interessant alternativ ud i kategorien "kunst" (fiktion).

For sin opretholdelse af positionen relativt nærmere kernen, med den relativt mere perifert positionerede kvalitative forskning som den nødvendige og bekvemme modpol positionen blandt andet opretholdes af - for opretholdelsen af denne videnskabeligt mere prestigefulde position må altså visse former for kvantitativ empirisk forskning leve med et vist selvbedrag og acceptere en reduktion i kreativ udfoldelse.

Den kvalitative empiriske forsknings andetgjorte position rummer på samme måde både muligheder og begrænsninger. Begrænsningerne ligger $\mathrm{i}$ den relative marginalisering og dermed den relativt mere sparsomt udmålte adgang til at "agere" videnskabelig autoritet og herunder for eksempel deltage autoritativt $\mathrm{i}$ de processer, der med akademisk stemme cirkulerer definitionsmagt i forhold til den sociale virkelighed. Men i forlængelse af dette er det på den anden side heller ikke den samme form for 
autoritet, der skal forsvares: Den kvalitative forskning er ikke på samme måde som den kvantitative nødt til at forsvare og reproducere foregivne objektivitetsnormer, og derfor har den kvalitative forskning også mulighederne for at udfolde sig mere analytisk afprøvende og kreativt undersøgende - herunder metodologisk refleksivt i forhold til egne præmisser.

Andethedspositionen kan imidlertid også fange den andetgjorte i en uhensigtsmæssig selvreproducerende dynamik, der kan fungere nok så destruktivt $\mathrm{i}$ forhold til såvel ambitionerne om kreativ udfoldelse som eventuelle ambitioner om at nærme sig adgang til den videnskabelige autoritets stemmer: Overtager man dualismen mellem subjektiv og objektiv og dermed positioneringen af egen forskning som "byper-subjektiv" eller som særligt permissiv: Identificerer man sig med andre ord med (tillader man sig identificeret med) holdningen "anything goes", vil den kvalitative empiriske forskning selv bidrage til opretholdelsen og forstærkningen af den dualistiske konstruktion mellem kvantitativ og kvalitativ metode. "Anything goes" er, som Scheurich har påpeget det, et fantasifoster, eftersom også den kvalitative forskning har stærke bin-dinger knyttet til forskningens betingelser for intersubjektiv genkendelse (Scheurich, 1997, p39).

$\mathrm{Nu}$ skal vi imidlertid gå mere detaljeret ind i nogle af de faser af forskningsprocessen, som bliver interessante, når man sammenligner kvalitative og kvantitative tilgange: formuleringen af forskningsspørgsmål og de analytiske fremgangsmåder.

\section{FORSKNINGSSPØRGSMÅL OG}

\section{ANALYTISKE PERSPEKTIVER}

I en vis forstand er faseopdelingen i en empirisk forskningsproces en rekonstruktion med det formål at skabe overblik. I den levede forskervirkelighed vil generering af forskningsspørgsmål naturligvis ligge forud for valg af indsamlings- og analysemetoder, men forskningsspørgsmålene kan meget vel tænkes at udvikle sig undervejs. Analysen udvikler sig som en underliggende refleksionsstrøm under hele forløbet og informerer dataorganiseringen og til tider også datagenereringen. Arbejdet med det empiriske materiale vil typisk frembringe nye ideer om typer af resultater, der skal inkorporeres i forskningsprocessen, og på den måde vil der være tale om en stadigt spiralformet bevægelse, hvor udvikling af forskningsspørgsmål, dataorganisering og muligvis også datagenerering samt analyse, væves sammen i en spiralformet proces. For klarhedens skyld vælger vi alligevel to "faser" ud som fokuspunkter her, men beder læseren om at holde den nævnte relativering af faseopdelingen in mente undervejs.

De typer af forskningsspørgsmål, som den socio-kulturelt analytiske type af empirisk forskning baserer sine undersøgelser på, retter sig oftest mod flere formål:

Til forskningsambitionen hører (hvad der måske oftest forbindes med det kulturanalytiske aspekt) en udfoldelse af handlerummets kompleksitet og af varierende former for kulturelle mønstre. Den socio-kulturelt analytiske forsker interesserer sig for at nuancere og komplicere det tilsyneladende selvfølgelige, de forenklede, common sense diskursiverede, eventuelt grovkategoriserede frenomener.

Den kvantitative tilgang vil ofte foretage denne nuancering og komplicering på store datasamlinger og f.eks. skabe nye og mere informative kategorier ved kombination af flere enkeltobservationer. Det er også i nykonstruktionen af specificerede underkategorier og i krydsgående analyser på tværs af hverdagskategoriers tidligere taget-for-givne opdelinger, at den kvantitative tilgangs "dekonstruerende" ambitioner findes, men samtidig her de finder deres klare begrænsning. Det er ikke muligt med kvantitative redskaber at "dekonstruere" i begrebets egentlige forstand: at opløse, problematisere, destabilisere og eventuelt erstatte kategoriale dikotome konstruktioner, magtpro- 
ducerende betydninger og konstituerende effekter i forhold til diskursiv magt og subjektivering. Men den opløsning af selvfølgliggjorte kategorier og nykonstruktion af andre, mindre, skæve, overraskende kategorier, en socio-kulturelt funderet kvantitativ forskning kan udvikle, skal til gengæld ikke undervurderes i forhold til konstruktionsproblematiserende og diskursivt opbrydende effekter. Der kan ad disse veje meget vel skabes opbrud i vores sædvanlige måder at forstå og praktisere diskursive kategorier på.

De nævnte dekonstruerende ambitioner vil til gengxld ligge mere direkte indbygget i den kvalitative socio-kulturelt analytisk empiriske forskning. Den kvalitative tilgang vil søge ind i mere detaljerede diskursive og kulturelle processeringer af betydningsskabelsespraksiser- og dynamikker. Den vil undersøge kulturelle redskaber for eksempel i form af en given konteksts centrale fælles narrativer og fælles tolkningsrammer, og dernæst undersøge konkret situerede individers overtagelse af dem, for eksempel som det ses i selv-narrative bestræbelser. Falles for de to tilgange er ambitionen om at $u d$ folde, komplicere og problematisere det selvfolgelige.

Lidt mere konkret eksemplificerende vil den kvalitative undersøgelse kunne formuleres som rettet mod, hvilke subjektiveringsbetingelser for eksempel folkeskolen eller universitetet eller særlige organisationer og arbejdspladser er rammen om: Hvad er betingelserne, hvordan tages de i brug, hvilke sociale landskaber resulterer ibrugtagelsen i med varierende former for differentieringer og in- og ekskluderinger indenfor givne aktørgrupper? Hvordan bevæges betingelserne, hvilke dynamikker, modsætninger, udviklingstendenser og brud er aktive $\mathrm{i}$ rummet?

Tilhør til særlige sociale kategorier kan også typisk være genstand for undersøgelse og udforskning, ikke mindst når forskningen netop drejes i mere konstruktionistisk og poststrukturalistisk inspirerede retninger. I forhold til sådanne socio-kulturelle kategorier vil den kvalitative undersøgelse af diskursive formationsbetingelser, f.eks. undersøgelsen af subjektiveringsprocesser i Foucault'sk og Butler'sk forstand, stå centralt. Man vil som forsker være interesseret i positioneringpraksiser indenfor afgrænsede handlerum, i forhandlinger af den sociale virkelighed i form af direkte konstruktionsbestræbelser rettet mod de omtalte typer af socio-kulturelle kategorier og disses tolkningsrammer og handlerum og/eller i form af mere indirekte konstruktionsbidrag aktualiseret gennem konkrete subjektiveringsprocesser og de revideringer af subjektpositioner, som disse processer kan indebære etc. Forskningsprocessen aktualiserer således spørgsmål af typen: Hvad betyder det at identificere sig med og/eller blive identificeret med denne eller hin kategori? Hvilke subjektiverende konsekvenser kan det have? Hvordan søges kategorien bevæget og "forhandlet" af de, der subjektiveres indenfor den og af de, der subjektiveres mere eller mindre eksplicit i modsætning til den?5

Den kvantitative forskning vil med en tilsvarende grundlæggende forståelse af det menneskelige og det sociale og kulturelle som gensidigt konstituerende have sit primære fokus rettet mod udforskningen af sociale landskaber og formationsbetingelser, for eksempel mod det at finde overraskende og informative ligheder mellem grupper, der i udgangspunktet blev opfattet som forskellige eller forskelle inden for grupper, der umiddelbart blev antaget for ens. Det er endvidere ambitionen at konstruere relativt enkle udtryk, der gør det muligt at beskrive komplekse sammenhænge uden at miste vesentlig information, at skabe kategorier, der kan overskride og nuancere det tilsyneladende selvfølgelige og at beskrive bevægelser i tid og rum.

Vil man f.eks. undersøge køn inden for et bestemt forskningsområde 6 er det naturligt at tage udgangspunkt i en optælling af mænd og kvinder på feltet. Men undervejs i undersøgelsesprocessen kan de kategoriale fokuseringer skifte fra at have de første sim- 
ple dualistiske kønskategorier som søgepunkt, til for det første at inddrage en historisk dimension, dernæst at krydse kategorierne med fagfeltskategorier igen undersøgt i deres historiske forløb, for endelig eksempelvis at inddrage uddannelseskategorier som en ny dimension i analysen. $\mathrm{Og}$ man kunne have fortsat opbrydningerne og krydsanalyserne. Man kunne også have inddraget kvalitative forskningsredskaber for at bringe forståelsen videre i en anden dimension for eksempel i forhold til at undersøge interaktionsdynamikken mellem de subjektiverede kvinders "valg" af fag og karriereveje/de subjektiverende betingelsers "fravalg” af samme kvinder, sådan som dette tænkes at ske gennem konkrete individers overtagelse og praktisering af tilgxngelige diskurser i det fælles praksisfelt.

For at få ideerne til sådanne og videre opbrud i kategorier og til rekonstruktionen af nye kategorier, må man imidlertid have adgang til de grundlæggende, metateoretiske forståelser af subjektiveringsprocesser, af diskursive formationsbetingelser, og dermed mere teoretisk specifikt af videnskabelige diskurser som historisk situerede og magtproducerende og af køn som konstruktion. Har man ikke det, fanges den analytiske fantasi ind langt tidligere i processen - forskerens analytiske spørgsmål hænger fast i common sense kategorier og common sense forståelser af visse tings og tilstandes uforanderlige og naturlige væren.

Nogle af forskellene mellem de to forskningsmåder ligger således i den kvalitative tilgangs mulighed for også at fokusere på subtile dynamikker i forhold til subjektivering og diskursiv processering, mens den kvantitative forsker i højere grad retter sine bestræbelser mod at afdække effekterne af disse dynamikker og processer med hensyn til givne aktørers positioner $\mathrm{i}$ det sociale landskab. Men det metateoretiske udgangspunkt er stadig det samme.

Med sådanne forskningsambitioner, ønsker både den kvantitative og kvalitative analytiker at skaffe sig et empirisk materiale, som giver mulighed for at undersøge og beskrive socio-kulturelle betingelser og de positioner, aktører henvises til og overtager indenfor disse. Men ofte vil ambitionen række videre end til selve beskrivelsen. Ambitionen vil også strække sig til ønsker om at destabilisere disse betingelser (Søndergaard, 1999/2000), eller som et minimum at åbne dem og deres tilknyttede selvfølgeligheder for refleksion og eventuel forandring eller gentilegnelse på nye præmisser (Davies 1990; Lather 1991; Butler 1995; Weedon 1997).

Udfoldelsen, nuanceringen og kompliceringen af handlerummets kulturelle mønstre (Gulbrandsen, 1998) vil ske gennem gen-fortxlling, re-narration, fra et andet perspektiv, og dette andet perspektiv - det at fortælle kulturen fra et perspektiv, der ikke bare ligger i kulturen selv (Geertz, 1993 (opr.1973)) - kan bringes i stand på flere måder. Typisk vil udfoldelsen og kompliceringen foregå gennem mødet mellem på den ene side teoretiske perspektiver og deres konkretisering i konkret empirisk rettede analytiske perspektiver og på den anden side empiriens kakafoni af stemmer og billeder.

Kombineret hermed kan indenfor den kvalitativt metodiske tilgang også inddrages en eksplicit og aktiv brug af forskersubjektets selvinvestering (en antropologisk udviklet fremgangsmåde, Hasse (2000)), hvor subjektets egen hidtidige subjektivering bevidst anvendes som “det fremmede" og gradvist transformerede, der frembringer et "andet perspektiv" på den udforskede kontekst. Kirsten Hastrup anvender begrebet forbløffelse om det, der sker med forskersubjektet i mødet mellem sådanne perspektiver, og forbløffelse bliver altså her det, der giver afsæt for re-narration (Hastrup, 1992). Re-narrationen bliver i den kvantitative forskning mulig på grundlag af de nye og krydskonstruerede kategorier og deres problematiseringer af feltets sammenhænge.

Når man således arbejder med et konkret 
datamateriale, vil dette materiale give anledning til udvikling af helt konkrete analytiske spørgsmål, der systematisk kan anvendes som mønster-søgningsredskaber indenfor netop disse data. Arbejder man kvalitativt med for eksempel subkulturelle identitetsformer vil disse konkrete analytiske spørgsmål se anderledes ud, end hvis man arbejder med for eksempel ledelsesdiskurser i dansk industri. Forskningsambitionerne konkretiseres helt specifikt i forhold til det givne forskningsfelt, men oftest med de overordnede analytiske vinkler, der har diskursive formationsbetingelser og subjektiveringsprocesser som omdrejningspunkt.

Arbejder man med kvantitative data, vil de kategoriseringer, man bruger, være udformet $\mathrm{i}$ forhold til de stillede forskningsspørgsmål. Det gælder f.eks. detaljeringsgraden. Vil man på europæisk plan undersøge kønsfordelingen på universiteterne, deler man måske de ansatte op efter land, køn og fag, og efter om de er professorer eller ej, mens en opdeling som den, der blev brugt til at undersøge køn i den medicinske forskning, hvor man gik i detaljer med uddannelse og speciale inden for fag, kunne føre til fejlslutninger, fordi de grupper, man fik defineret, slet ikke var sammenlignelige over et så stort område. I senere delundersøgelser vil man så kunne udvælge og forfine kategorisering. De eksisterende registre og officielle databaser sætter imidlertid ofte grænser for, hvilke forskningsspørgsmål man kan stille.

Og stadigvæk foregår analysen indenfor både den kvalitative og den kvantitative tilgang som en søgning efter mønstre og en åbning af det selvfølgelige. Det indebærer komplicering af det lukkede og taget-forgivne og i den kvalitativt analytiske del i en eksplicitering af diskursive betingelser for produktionen af det selvfølgelige og af subjektiveringens præmisser og dynamikker.

Denne mønstersøgning, åbning, komplicering, eksplicitering og nuancering foregår gennem stadige gennemgange af datamaterialet og stadige parallelle tekstskrivninger.
Bemærk at den kvantitative forsker ikke, som ofte antaget, arbejder med færdige hypoteser, der blot verificeres eller falsificeres gennem en eller to kørsler af data. Han eller hun prøver, søger, får nye ideer til sammenhænge, skaber halve prøvende fortællinger om sine data, laver kørsler der viser, at fortællingen ikke holder og må brydes op, udvikler nye ideer der igen giver ophav til nye kørsler, nye fortællinger etc. I den proces er de løbende tekst(gen)skrivninger vigtige.

I første omgang er den kvantitative og den kvalitative tilgangs tekstskrivninger og deres udvikling af pointer "flade" og for det meste nok så skuffende. Dette kan få mange til at opgive den empiriske sociokulturelle analyse. Det tager tid, før den giver de erkendelsesmæssige kicks, der driver en forskningsproces. Men gradvist vil dialogen mellem forsker og datamateriale bevæge sig ind i en proces, hvor "det nye" sker, som resulterer i en re-narrativ virksomhed, der fungerer åbnende, ekspliciterende og komplicerende. En proces, der skubber forskerens erkendelse til grænserne og giver overskridende indsigter i det undersøgte felt.

De mange gentagne læsninger af data fører til, at pointer og mønstre genereres og gøres til genstand for refleksion. Det er som nævnt en proces, der rejser nye analytiske spørgsmål, som igen anvendes i fornyede gennemgange af data, hvilket afstedkommer flere og nye pointer og mønstre, som kan gøres til genstand for refleksion, som rejser nye analytiske spørgsmål, der igen kan anvendes i gennemgangen af data, hvilket .... etc.

Denne beskrivelse gælder som nævnt ikke bare for den kvalitative, men også for den kvantitative empiriske analyse. Selv i kvantitative analyser, der munder ud i et eller flere statistiske tests, er der typisk gået en lang modelformuleringsprocedure forud, hvor man via grafiske undersøgelser, beregning af summariske numeriske størrelser, tentative sammenlægninger eller opde- 
linger af grupper, afgrænsning af datamaterialet, eventuelle pilotundersøgelser etc. prøver at nå frem til et system, der både kan analyseres og er informativt i forhold til de stillede forskningsspørgsmål. ${ }^{7}$ Processen er på sin vis narrativt søgende, selvom den kvantitative forskning ikke kan påstås at være narrativ i en mere klassisk betydning af begrebet. En sådan kan f.eks. hentes hos Bruner, der om narrativitetsbegrebet skriver:

"Perhaps its principal property is its inherent sequentiality: a narrative is composed of a unique sequence of events, mental states, happenings involving human beings as characters or actors. These are its constituents. But these constituents do not, as it were, have a life or meaning of their own. Their meaning is given by their place in the overall configuration of the sequence as a whole - its plot or fabula. The act of grasping a narrative, then, is a dual one: the interpreter has to grasp the narrative's configuring plot in order to make sense of its constituents, which he must relate to that plot. But the plot configuration must itself be extracted from the succession of events" (Bruner 1990, 43-44).

Den kvantitative tilgang vil ikke operere med alle disse elementer i sine forskningsrapporterende sammendrag - og alligevel vil søgningen efter plottet i data'ene, historien som disse data kan siges at fortælle, det der i disse data fremviser sammenhænge og forløb og bevægelser på nye måder, styre analyseprocessen.

\section{RESULTATER OG FORMIDLING}

Typen af resultater, som den socio-kulturelt analytiske empiriske forskning kan frembringe, formidler indsigt, nye erkendelser af sammenhænge og forståelser (versus forklaringer). For den kvalitative del vil det være viden om konnotationssammenhænge, subjektive procesdynamikker, in- og ekskluderende processer etc., som formuleres i re- sultatteksten. For den kvantitative del vil det være viden om ændringer $\mathrm{i}$ positioner over tid, sammenhænge mellem forskellige positioner, hierarkiseringer, problematisering af tilsyneladende sammenhænge. Integreret heri kan forskningen frembringe nye refleksionsredskaber i form af generaliserbare forståelsesmodeller og begreber - for den kvalitative del vil det være en eksplicit ambition.

Resultaterne i den kvalitative del vil typisk blive formidlet gennem en kombination af det, der i en Bruner'sk terminologi kaldes for paradigmatiske overblik (Bruner, 1990) (en beskrivelse af relativt nemt tilgængelige mønstre og variationer i tilstande og situationer indenfor det undersøgte felt) og det, der gennem narrative greb og refleksionsekspliciterende tekstbidder kan fremmes af forståelser og indsigt i det undersøgte felts mere subtile dynamikker.

Det er væsentligst i denne sidste del, at det komplicerende og dekonstruerende bliver tilbudt læseren. Tilbuddet sker gennem et narrativt greb, der på een gang dokumenterer indsigtens genereringsbasis i data'enes møde med forskerens teoretisk informerede analyse - og gør indsigten indfølelig, vi kan også kalde den: erfaringsformidlet eller læsesanseligt tilgængelig, gennem dens fortalte og narrativt inviterende form. Det, narrativerne kan, er blandt andet at invitere til med-leven. Og det er denne med-leven, som giver en særlig dimension til erkendelsesprocessen, når det drejer sig om at formidle nye indsigter og forståelse. Narrativeets dokumenterende og forståelsesfaciliterende funktion bliver $\mathrm{i}$ denne forstand basis for de refleksionsudhævelser, der dernæst som et tredje element, løber gennem de socio-kultuelt analytiske tekster. Her destilleres den refleksion og forståelse frem, som narrativerne (der igen er støttet til de paradigmatiske overblik) er præsenteret med henblik på.

Ligesom den kvalitative tilgang anvender narrative greb til at støtte forståelsen, så har den kvantitative tilgang en række virkemid- 
ler, f. eks. grafiske, med samme formål. Ser man i Homo Academicus (Bourdieu, 1984) på den korrespondanceanalytiske fremstilling af feltet for franske fakulteter, så bruges "kortet" narrativt, ved at topografien (nærhed/fjernhed, op/ned) billedligt formidler sammenhænge i det studerede felt. (Samtidig indeholder figuren en rigdom af oplysninger langt ud over, hvad Bourdieu bruger i sine analyser, og læseren kan selv kan gå på jagt efter fund, der kan give indsigt $\mathrm{i}$ helt andre sammenhænge).

Nærmere ved den kvalitative forsknings narrative greb ligger den kvantitative forskers mulighed for at presentere en serie af tabeller, der fortæller en historie i større og større detalje; ofte suppleret med tabeller, der forholder sig til mulige indvendinger mod de fremsatte udsagn. Figurer og andre grafiske fremstillinger bærer $\mathrm{i}$ en vis forstand en "narrativ" værdi, og her har den teknologiske udvikling skabt nogle muligheder for fortælling, som langt fra er udnyttet godt nok. Det er i øvrigt interessant, at kvantitative analyser ofte formidles helt uden brug af tal, men med vægten lagt på de visuelle virkemidler i form af grafer, diagrammer, plots etc.

\section{AFSLUTNING}

Som vi har forsøgt at vise gennem en mere konkret sammenligning mellem socio-kulturelle kvantitative og kvalitative tilgange til empiriske studier, vil de frlles kundskabsambitioner og det fælles metatoretiske udgangspunkt, som sådanne studier deler, resultere i typer af forskningsprocesser, der trods de konkret metodiske redskabers forskellighed alligevel bevæger forståelsen udover de dualistiske metodeforestillinger, der hersker indenfor en del fagdiscipliner om relationen mellem kvantitative og kvalitative traditioner. Den mønstersøgende og nysgerrige analytiske fremgangsmåde, de nybrydende og ofte diskursivt destabiliserende ambitioner konkretiseres forskelligt og har på grund af de tilgængelige forsk- ningsredskaber forskellig rækkevide, men ligger ikke desto mindre som fælles gods hos forskere fra begge traditioner.

Når den kvantitative empiriske forskning ikke udelukkende henvises til at indtage en position som "objektiv", bevisende og sandhedssøgende, så peger det - sammen med vores forsøg på at eksplicitere fælles træk i de metodiske fremgangsmåder og deres baggrund i fælles metateoretiske positioner og kundskabsambitioner - på behov for gentænkning af forskningstilgangenes hierarkiske positionering i forhold til hinanden, sådan som vi skrev om det tidligere i artiklen. Opløses den gensidigt lukkende positionering sammen med hierarkiseringen, vil de kvantitative redskaber kunne anvendes på en alternativ og erkendt historisk og kulturelt situeret måde. De gensidige myter kvantitative og kvalitative tilgange imellem vil kunne udfordres og bevæges, og der vil formentligt kunne skabes basis for et mere udbygget samarbejde mellem de to traditioner.

\section{Noter}

1. Kønsbarriereprojektet er et femårigt tværforskningsrådsligt initiativ, der skal afdække kønssegregering i forskningen og på de højere uddannelser i Danmark. Forfatterne deltager begge i delprojektet Kon i den Akademiske Organisation, som er et af fire delprojekter under initiativet.

2. Allerede oldtidens græske matematikere sondrede mellem analyse og syntese. Syntese var fremstilling af løsningen af et problem, først og fremmest altså beviser. Analyse var procedurer der førte til opdagelsen eller konstruktionen af beviser. Man skelnede altså mellem den situation, hvor der konstrueredes et bevis og så den situation hvor man beskrev dette bevis. Kun den sidste del var offentlig. Tilblivelsesprocessen havde ingen interesse for andre.

3. Den hierarkisering af kvantitativ og kvalitativ forskning, vi omtaler i det følgende, skal igen ses i lyset af det tidligere omtalte hierarki mellem de mere prestigetunge eksperimentelle og de mindre prestigetunge empiriske undersøgelser. Se for eksempel Polkinghorne (2001) for en diskussion af den videnskabshistoriske baggrund for dette fænomen. 
4. Se Hasses (1999) beskrivelser af "fortællingen om eksperimentet" som et vigtigt led i opdragelsen til fysiker. Inden for lægevidenskab finder man på mange områder en tilsvarende næsten rituel understregning af "den naturvidenskabelige metode", f. eks. i opfattelsen af (dobbelt)blinde, randomiserede forsøg som indiskutabelt bedste forskningsmetodik.

5. Den konstruktionistisk og/eller poststrukturalistiske, empiriske forskningspraksis varierer på et vist detaljeringsniveau fra den socio-kulturelle, empiriske forskningspraksis i rækkevidden af sin analytiske fantasi: førstnævnte har en udstrakt og radikalt konstruktionistisk opfattelse af sin forskningsgenstand, og ser dens socio-kulturelle og historiske specifikationer i lyset af en potentiel meget vidtgående dekonstruktion. Mens f.eks. dele af den socio-kulturelt psykologiske (kulturpsykologiske) tradition endnu har tilstrækkelig mange bindinger til den virksomhedsteoretiske og sovjetpsykologiske forskningspraksis (som i sin oprindelige modernistiske og sandhedssøgende form havde alment bestemmende formål rettet mod psyko-sociale fænomener) til at denne grad af dekonstruerende fantasi ligger udenfor rækkevidde.

6. Se Henningsen (1998) for en sådan analyse af det lægevidenskabelige område.

7. Se f.eks. fremstillinger af den matematiske modelleringsproces i Niss 1991.

\section{LITTERATUR}

- Almegård, Ann (1997): Disputerade medicineres forskarkarriär - i ett könsperspektiv. Jämställdhetsrapport $\mathrm{Nr}$ 2-1997.

- Benzécri, Jean-Paul et al (1972): L'Analyse des

Donnés. II. L'analyse des correspondances. Dunod, Paris.

- Bourdieu, Pierre (1984): Homo Academicus. Politiy Press, Cambridge.

- Bruner, Jerome (1990): Acts of Meaning.

Harvard University Press, Cambridge, Massachusetts.

- Butler, Judith (1993): Bodies that Matter: On the Discursive Limits of "Sex". Routledge, London and New York.

- Butler, Judith (1995): Contingent Foundations. I Feminist Contentions. A Philosophical Exchange. Introduction Linda Nicholson. Routledge, London and New York.

- Butler, Judith (1997): The Psychic Life of Power. Stanford University Press, Stanford.

- Cole, Michael (1996): Cultural Psychology. A once and future discipline. Harvard University Press, Cambridge, Massachusetts.
- Davies, Bronwyn (1990): The Problem of Desire. Social Problems 1990/3.

- Davies, Bronwyn (2000): A Body of Writing 1990-1999. Alta Mira Press, New York.

- Davies, Bronwyn and Rom Harré (1990): Positioning: The discursive production of selves. Journal for the Theory of Social Behaviour 1990/1.

- Foucault, Michel (1978, opr.1976): Seksualitetens Historie. Bibliotek Rhodos, København.

- Geertz, Clifford (1993, opr.1973): The Interpretation of Cultures. Fontana Press, London.

. Gulbrandsen, Mette Liv (1998): I barns dagligliv. En kulturpsykologish studie av jenter og gutters utvikling. Universitetsforlaget, Oslo.

- Hasse, Cathrine (2000): Kulturelle lareprocesser $i$ det fysiske rum. Phd-afhandling, Institut for Antropologi, Københavns Universitet.

- Hastrup, Kirsten (1992): Det antropologiske projekt om forbløffelse. Gyldendal, København.

- Henningsen, Inge (1998): Lægevidenskab og køn. En analyse af det lægevidenskabelige område på Købenahvsn Universitet med henblik på en kortlægning af kvindernes placering blandt de videnskabeligt ansatte. Køn $i$ den Akademiske Organisation. Institut for Statskundskab, Københavns Universitet.

- Haavind, Hanne (1987): Liten og Stor. Universitetsforlaget, Oslo.

. Haavind, Hanne (1994): Kjønn i forandring som fenomen og som forståelsesmåte. Tidsskrift for Norsk Psykologforening 1994/9.

- Lather, Patti (1991): Getting Smart: Feminist

Research and Pedagogy With/in the Postmodern.

Routledge, London and New York.

- Lather, Patti (1993): Fertile Obsession: Validity

After Poststructuralism. The Sociological Quarterly $1993 / 4$.

- Niss, M. et al (1991): Teaching of Mathematical Modelling and Applications. Ellis Horwood, London.

- Polkinghorne, Donald (2001): Human Science and Praxis. State University of New York Press, New York. (in press)

- Sheurich, James (1997): Research Method in the Postmodern. Falmer Press, London and Washington, D.C.

- Søndergaard, Dorte Marie (1996): Tegnet på Kroppen. Køn: Koder og Konstruktioner blandt Unge Voksne i Akademia. Museum Tusculanums Forlag, København.

- Søndergaard, Dorte Marie (1999): Destabilising Discourse Analysis: Approaches to Poststructuralist Empirical Research. Working Paper no.7, Gender in the Academic Organisation (distributed by the Department of Political Science, University of 
Copenhagen). (Dansk udgave publiceres (2000), i Kjønn og Fortolkende Metode, Haavind (red.). Gyldendal Akademisk, Oslo)

- Weedon, Chris (1987): Femist Practice Et Poststructuralist Theory. Blackwell Publishers, Oxford.

\section{SUMMARY}

The article takes up the discussion about qualitative and quantitative research methods as ostensibly incompatible approaches to empirical studies - an understanding which is broadly disseminated within a range of academic disciplines. The authors trouble this dualistic understanding through concrete discus- sions of methodological approaches conducted by as well qualitatively as quantitatively oriented reseachers. It is argued, that difference and potential incompatibility must be seen in relation to the metatheoretical basis for the studies and thereby in relation to the research ambitions, in which the studies are involved.

Inge Henningsen, cand.stat.

lektor ved afdeling for statestik og operationsanalyse Københavns Universitet

Dorte Marie Søndergaard: dr.philos et cand.psych. lektor ved institut for psykologi og filosofi Roskilde Universitets Center 